\title{
Research on the Service Innovation Path for Information Platform in the Cloud Computing Environment
}

\author{
Changyun Li, Hongyu Kang and Si Chen \\ School of Management, Harbin University of Science and Technology, Hei \\ Longjiang Harbin150040, China \\ lichangyun1966@163.com
}

\begin{abstract}
To reveal the mechanism of information platform service innovation in cloud computing environment, the hypothesis of the interactive relationship among cloud computing, service innovation middle variables, and service innovation performances was put forward in this thesis based on the investigation of relevant domestic and foreign literatures. The research chooses the information platform of logistics industry as an example, which was proceeded by constructing the structural equation model of the maximum likelihood estimate method with questionnaires about the logistics information platform in all provinces and municipalities. The result suggested that cloud computing can affect the service innovation performance of information platforms through its significant positive impacts on service concept innovation, service interface innovation and service delivery innovation, which can act as the theoretical foundation for the operation and development of the information platform.
\end{abstract}

Keywords: Cloud computing, Information platform, Service innovation, Structural equation

\section{Introduction}

With the increase in the number of information platform integration of resources and the era of big data explosive growth, the information platform must carry on the continuous service innovation to provide users with more accurate, convenient and effective service. Information platform is based on information technology with fully integrating the resources of data, information, knowledge and optimizing business processes, and plays an important role in promoting open sharing of information resources and improving service efficiency and management level. Today, the increasingly sophisticated cloud computing technology breaks the limits of the traditional IT infrastructure capabilities with the advantages of flexibility, elastic, scalability, resource pools and so on, and provides a new way of thinking for information platform service innovation with the flexible IS architecture. However, the issues of the mechanism and path of information platform service innovation are being explored, as cloud computing is a new generation of information technology. Therefore, this study establishes the concept model of information platform service innovation to reveal the mechanism of service innovation of information platform in cloud environment regarding three innovative elements of service concept, service interface and service delivery as intermediate variables, starting from the characteristics of cloud computing, which has important theoretical value and practical guiding significance for exploring information platform service mode innovation.

Information platform service innovation means that the information platform adopts new ideas, new technologies in the service process to improve the existing service flow and service products, the existing service quality and service efficiency and create new 
value for customers, which will finally form the competitive advantage of information platform. In 1998, Bilderbeek proposed an integrated conceptual model concerning service innovation which is called the "four dimensional model". The model used structured methods to divide the content of service innovation into four categories, namely, the new service concept, new customer interface, new service delivery and new technology [1]. As the information technology which is the support elements of service innovation is not on the same level with the other three dimensions of service innovation, it will be independent from the dimension of innovation and regarded as an important factor supporting the other three dimensions of innovation [2], but there are few theoretical research results about service innovation from the perspective of cloud computing technology. Therefore, the driving functions of cloud computing technology and service concept innovation, interface innovation, delivery innovation can be studied in order to reveal the effect mechanism of cloud computing technology for the information platform service innovation. This research enriches the theory of service innovation proposed by Bilderbeek, and it is a subject worthy of further study.

\section{Research Hypothesis}

\subsection{Research Hypothesis for Service Concept Innovation of Information Platform a) Cloud Computing and Service Concept Innovation of Platform}

Cloud computing is essentially a new generation of IT infrastructure (Delen D etc., 2013) [3], cloud computing is more flexible in scheduling and the deployment of IT resources (Buyya R etc., 2009) [4]. The elasticity, scalability, ubiquitous access and pay-for-use of cloud computing make information platform to make use of cloud resources more flexible; At the same time, the characteristic of cloud computing, the data concentration, the resource pool and sharing environment, enhanced the integration capabilities of information platform in the data and software (Mcafee, 2011) [5]. Therefore, on the perspective of the demand of the service innovation, the main characteristics of cloud computing are "flexibility" and "integration", which are the two main features of the cloud computing.

Service concept innovation is to provide customers with a new or improved service contents or functions, through to comprehensive analysis of customer demands (Wang Lin etc., 2009) [6], in order to provide more efficient and accurate services for target customers. By the flexibility of cloud computing to construct information platform, gathering, processing and mining the information resource, comprehensive analysis of customer needs, and improve the value-added services of information platform. The integration of cloud computing is able to promote information sharing between enterprises and customers on information platform, which create a new way for enterprise and customer communication, providing customized personalized service to our customers. Cloud computing can not only improve the channel of knowledge transfer, to make the entities of knowledge supply and demand are more diverse, but also can support many new mechanisms of service concept innovation (Li Changyun, 2012) [7], and provide new services to customers ultimately. Based on the above analysis, this paper proposes the following hypothesis:

H1: The flexibility of cloud computing has a positive effect on the service concept innovation

H2: The integration of cloud computing has a positive effect on the service concept innovation

\section{b) Service Concept Innovation of Platform and Service Innovation Performance}

Service concept innovation refers to the information platform based on the needs of 
customers and the environmental changes, forming the "new" understanding of shared service. Through the new concept or new method to development and design services, improving the utilization of idle resources (Yin Chao etc., 2011) [8], improved the operational efficiency of the information platform and the service innovation performance. Information platform can realize the height of the resource gathering by getting multi-channel information resources from the government, enterprises and customers, having quick response ability to the market changes and customer demands (Zhang Fangfeng etc., 2011) [9]. Information platform can focus on the collection of a large number of available information from each application subsystem (Yang Shuang etc., 2013) [10], giving full play to the powerful function of information platform, to provide decision service for users. Based on the above analysis, this paper proposes the following hypothesis:

H3: Service concept innovation has a positive effect on service innovation performance

\subsection{Research Hypothesis for Service Interface Innovation of Information Platform a) Cloud Computing and Service Interface Innovation of Platform}

Service interface of information platform is an interactive system to maintain the relationship between service providers and customers, it is the expression of the interface which is transmitted to customers, it is also a task interactive system between the main function and the main function of the service system. Through the flexibility and integration of cloud computing design and improve the service interface of information platform, on the one hand, it can help collect, arrange and process the customer demand information, to perceive customer preferences, potential demand. In the process of interaction with the customer, to attract customer attention by the vivid service interface, so as to provide customers with better service experience (Chen Ye, 2010) [11]; On the other hand, it is to optimize the allocation of information resources and the full range of sharing, for each level of the behavior of the main body to provide a full range of information services and auxiliary decision-making, In order to gain the competitive advantage in the process of interface interaction. Based on the above analysis, this paper proposes the following hypothesis:

H4: The flexibility of cloud computing has a positive effect on the service interface innovation

H5: The integration of cloud computing has a positive effect on the service interface innovation

\section{b) Service Interface Innovation of Platform and Service Innovation Performance}

In the information platform service system, interface innovation directly affects service activities of the interactive behavior, transfer information and other elements among enterprises, management department of platform, government and customers. The core purpose is to improve the way of communication and channels between main bodies, eliminate the obstacles of information circulation and share information deeply. It can significantly enhance economic efficiency (Hao Xinjun etc., 2015) [12], and enhance the overall performance of shared services to provide quality interactive environment. In the process of providing service, the service interface function innovation not only enhances the user's interactive experience, but also expands the market scope, which is conducive to the search for niche market. Based on the above analysis, this paper proposes the following hypothesis:

H6: Service interface innovation has a positive effect on service innovation performance 


\subsection{Research Hypothesis for Service Delivery Innovation of Information Platform a) Cloud Computing and Service Delivery Innovation of Platform}

Service delivery innovation is through the adjustment and transformation of existing technology and operational processes of service development, improved the efficiency and effectiveness of platform service delivery, in order to improve operational efficiency of platform and customer satisfaction (Wei Jiang etc., 2008) [13]. Flexibility of cloud computing, it makes the information system architecture of the platform is easier to expand, in order to quickly launch new business (Marston S etc., 2011) [14]. Cloud computing technology can support collaborative services between different functional information platforms, not only improve the operating efficiency of the platform, but also optimize the organizational structure (Liu Shunzhong, 2011) [15] and management mode of the platform service. By the integration of cloud computing realizes the visualization of service flow of information platform, such as shared information, data consistency and application integration, etc., which increased participation of customer and transparency of services. Based on the above analysis, this paper proposes the following hypothesis:

H7: The flexibility of cloud computing has a positive effect on service delivery innovation

H8: The integration of cloud computing has a positive effect on service delivery innovation

\section{b) Service Delivery Innovation of Platform and Service Innovation Performance}

Information platform can realize the dynamic sharing of information resources, providing the basis for dynamic monitoring of information platform by assessing the performance of service process and result (Li Yue etc., 2015) [16]. As the information medium, which provided information docking services for enterprises and customers, improved the efficiency of communication and feedback between the two sides; By adopting cloud computing technology and new management tools, optimized service process, ultimately improving the users value (Sundbo J etc., 1997) [17]. Taking advantage of cloud computing technology can meet the information platform which change organization structure and improve staff quality, continuously improving efficiency and quality of service. Based on the above analysis, this paper proposes the following hypothesis:

H9: Service delivery innovation has a positive effect on service innovation performance

\section{Research Design}

\subsection{Construction of Conceptual Model}

After information platform adopt cloud computing technology, According to the technical characteristics of cloud computing can be summarized as two indicators of flexibility and integration; through the analysis, three elements of cloud computing act on service innovation are selected, respectively with three variables: service concept, service interface and service delivery to scale, Through innovation of three intermediate variables improve service innovation performance. In summary, this paper constructed of the conceptual model of the mechanism of cloud computing for the information platform service innovation. It is shown in Figure 1. 


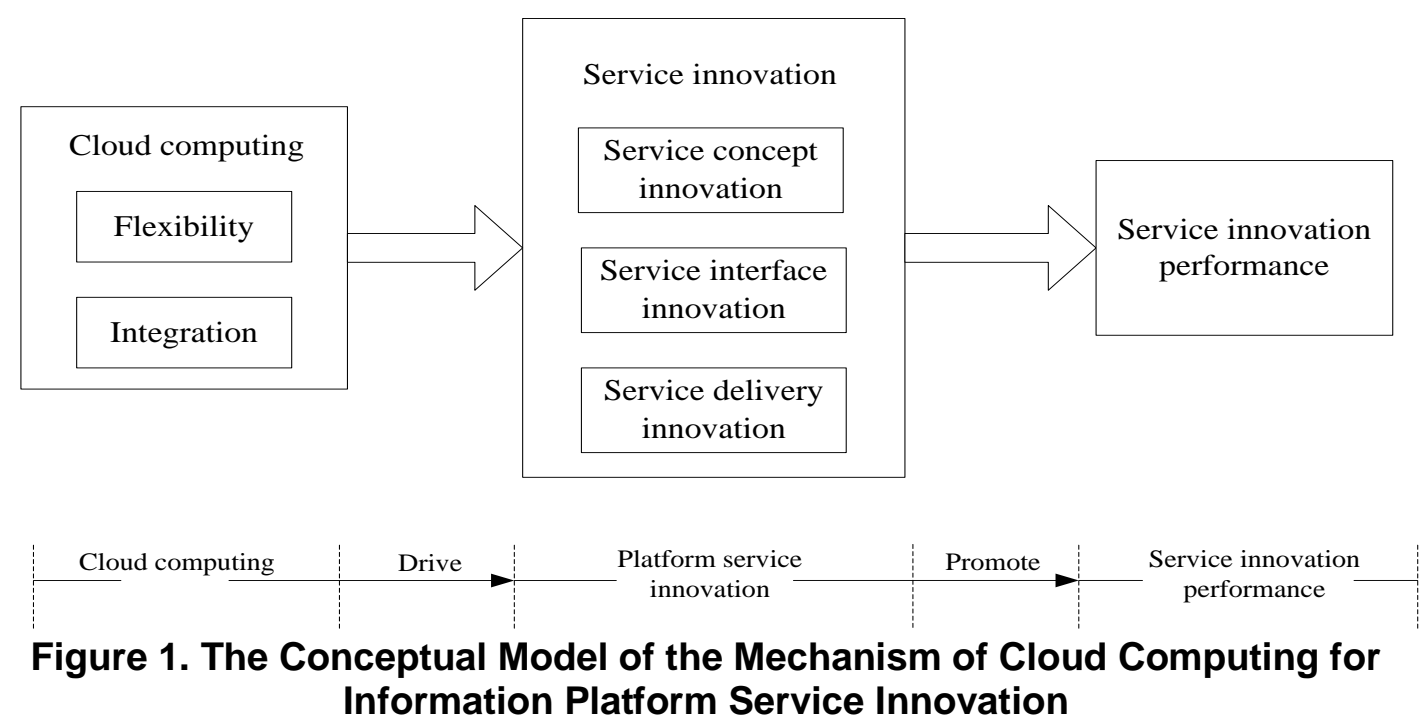

\subsection{Measured Variable}

In this research, combined with a large number of domestic and foreign literatures, this paper chooses the information platform of logistics industry as an example, the measurement index of the variables in the questionnaire was designed, as shown in Table 1.

\section{Table 1. Measurement Index System of the Mechanism of Cloud Computing for the Logistics Information Platform Service Innovation}

\begin{tabular}{|c|c|}
\hline $\begin{array}{c}\text { Latent variable } \\
\text { name }\end{array}$ & Measurement index \\
\hline \multirow{4}{*}{$\begin{array}{l}\text { Flexibility of cloud } \\
\text { computing }\end{array}$} & $\begin{array}{l}\text { Cloud computing can meet the customers access volumes of logistics } \\
\text { information platform }\end{array}$ \\
\hline & $\begin{array}{l}\text { Cloud computing can meet the needs of logistics information } \\
\text { platform for large data processing }\end{array}$ \\
\hline & $\begin{array}{l}\text { Cloud computing can meet the extension of service function of } \\
\text { logistics information platform }\end{array}$ \\
\hline & $\begin{array}{l}\text { Cloud computing can quickly adapt to changes of business volumes } \\
\text { of the logistics information platform }\end{array}$ \\
\hline \multirow{3}{*}{$\begin{array}{l}\text { Integration of cloud } \\
\text { computing }\end{array}$} & $\begin{array}{l}\text { Cloud computing promote the exchange and sharing of information } \\
\text { resources }\end{array}$ \\
\hline & $\begin{array}{l}\text { Cloud computing can optimize the configuration and full sharing of } \\
\text { logistics resources }\end{array}$ \\
\hline & $\begin{array}{c}\text { Cloud computing can realize the visualization of logistics information } \\
\text { platform service process }\end{array}$ \\
\hline \multirow{4}{*}{$\begin{array}{l}\text { Service concept } \\
\text { innovation }\end{array}$} & $\begin{array}{l}\text { Service concept innovation contribute to service development, plan } \\
\text { and design }\end{array}$ \\
\hline & $\begin{array}{l}\text { Service concept innovation provide more accurate service pack } \\
\text { through improved services }\end{array}$ \\
\hline & $\begin{array}{l}\text { service concept innovation for the new service make functional } \\
\text { analysis and formal design }\end{array}$ \\
\hline & $\begin{array}{l}\text { Service concept innovation enhance the users experience through } \\
\text { improved services }\end{array}$ \\
\hline $\begin{array}{l}\text { Service interface } \\
\text { innovation }\end{array}$ & $\begin{array}{l}\text { Service interface innovation help analyze users behavior data to } \\
\text { provide specialized services }\end{array}$ \\
\hline
\end{tabular}




\begin{tabular}{c|c}
\hline \multirow{4}{*}{$\begin{array}{c}\text { Service delivery } \\
\text { innovation }\end{array}$} & $\begin{array}{c}\text { Service interface innovation help users get better interactive } \\
\text { experience }\end{array}$ \\
\cline { 2 - 2 } & $\begin{array}{c}\text { Service interface innovation help improve the efficiency of } \\
\text { communication and feedback between the two sides }\end{array}$ \\
\cline { 2 - 2 } & $\begin{array}{c}\text { Service delivery innovation optimize service processes, improve } \\
\text { customer value }\end{array}$ \\
\cline { 2 - 2 } & $\begin{array}{c}\text { Service delivery innovation optimize the allocation of social logistics } \\
\text { resources through low-cost means }\end{array}$ \\
\hline \multirow{3}{*}{$\begin{array}{c}\text { Service innovation } \\
\text { performance }\end{array}$} & $\begin{array}{c}\text { Logistics information platform for the market changes, customers } \\
\text { demand with rapid response capability }\end{array}$ \\
\cline { 2 - 2 } & $\begin{array}{c}\text { Logistics information platform can enhance customer satisfaction and } \\
\text { improve customer value }\end{array}$ \\
\cline { 2 - 2 } & $\begin{array}{c}\text { Logistics information platform provide users with decision-making } \\
\text { services }\end{array}$ \\
\hline
\end{tabular}

\subsection{Data Source}

This research used method of questionnaire to collect data. The contents of the questionnaire include the running status of the logistics information platform of provinces and cities and the achievement of logistics information platform service innovation in the cloud computing environment. Logistics information platform of the survey distributed in Heilongiiang, Liaoning, Tianjin, Jiangsu, Zhejiang, Shenzhen and other places. The research object is the enterprise staff and administrators of 7 departments, such as the $\mathrm{R} \& \mathrm{D}$ department, warehouse department, transport department, business department, etc. of the logistics information platform, as shown in Table 2. Each item was measured by using 5-point Richeter scale. In the scale of "1" represents "strongly disagree", "2" for "comparative disagree", "3" stands for "uncertain", "4" stands for "inclined to agree", "5" stands for "strongly agree". The questionnaire survey was conducted by visiting, telephone, Internet, and e-mail. In this study, 200 questionnaires were distributed, 163 questionnaires were recovered, recovery of $81.5 \%$, in which 152 valid questionnaires parts, the effective rate of $93.25 \%$.

\section{Table 2.The Basic Situation of Various Departments Logistics Information} Platform

\begin{tabular}{c|c|c}
\hline $\begin{array}{c}\text { Various departments of logistics } \\
\text { information platform }\end{array}$ & Number of samples & Percentage \\
\hline R\&D department & 38 & $19 \%$ \\
\hline Warehouse department & 26 & $13 \%$ \\
\hline Transport department & 28 & $14 \%$ \\
\hline Business department & 25 & $12.5 \%$ \\
\hline financial department & 21 & $10.5 \%$ \\
\hline Information department & 33 & $16.5 \%$ \\
\hline Operation department & 29 & $14.5 \%$ \\
\hline Total & 200 & $100 \%$ \\
\hline
\end{tabular}

\section{Data Analysis and Results}

\subsection{The Selection of Research Methods}

Structural equation model is the integrated use of multiple regression analysis, 
confirmatory factor analysis and statistical modeling techniques of path analysis. It mainly has the effect of verification, its advantage is that can use simultaneously multiple variables, not only can handle numeric continuous variables, but also can deal with categorical variables, breaking the traditional theoretical model on measurement technology for the plight of lack of integration of analysis capabilities [18]. Because of the relationship among the influencing factors of potential variables are very complicated, structural equation model which has the trait of using multiple variables is suitable for this paper. Therefore, structural equation model is fit for this research.

\subsection{The Analysis of Reliability and Validity}

In terms of reliability test, with the help of Cronbach's $\alpha$ coefficient test the stability and internal consistency of various scales. Taking advantage of SPSS16.0 obtain the results shown in Table 3. By Table 3, shown, Cronbach's $\alpha$ coefficients of all scales are more than 0.7 , higher than threshold of reliability test, illustrating the scale used in this research has a good reliability.

In terms of validity test, we are used to cross factor load coefficient and AVE to test convergent validity and discriminated validity of the measurement model. By Table 3, shown, cross factor load coefficient of measures are higher than 0.7 and AVE are higher than 0.5 , which show measured variables can effectively explain the latent variables, measured variables have good convergent validity.

Table 3. The Test of Reliability and Validity

\begin{tabular}{|c|c|c|c|c|}
\hline Latent variable & $\begin{array}{l}\text { Measurement } \\
\text { index }\end{array}$ & $\begin{array}{c}\text { Cross factor load } \\
\text { coefficient }\end{array}$ & $\begin{array}{c}\text { Cronbach's } \alpha \\
\text { coefficient }\end{array}$ & AVE \\
\hline \multirow{4}{*}{$\begin{array}{c}\text { Flexibility of } \\
\text { cloud } \\
\text { computing }\end{array}$} & CF1 & 0.975 & \multirow{4}{*}{0.949} & \multirow{4}{*}{0.963} \\
\hline & CF2 & 0.977 & & \\
\hline & CF3 & 0.982 & & \\
\hline & CF4 & 0.968 & & \\
\hline \multirow{3}{*}{$\begin{array}{l}\text { Integration of } \\
\text { cloud } \\
\text { computing }\end{array}$} & CI1 & 0.915 & \multirow{3}{*}{0.924} & \multirow{3}{*}{0.943} \\
\hline & CI2 & 0.956 & & \\
\hline & $\mathrm{CI} 3$ & 0.937 & & \\
\hline \multirow{4}{*}{$\begin{array}{l}\text { Service concept } \\
\text { innovation }\end{array}$} & SCI1 & 0.904 & \multirow{4}{*}{0.885} & \multirow{4}{*}{0.912} \\
\hline & SCI2 & 0.875 & & \\
\hline & SCI3 & 0.883 & & \\
\hline & SCI4 & 0.894 & & \\
\hline \multirow{3}{*}{$\begin{array}{c}\text { Service } \\
\text { interface } \\
\text { innovation }\end{array}$} & SII1 & 0.945 & \multirow{3}{*}{0.935} & \multirow{3}{*}{0.952} \\
\hline & SII2 & 0.924 & & \\
\hline & SII3 & 0.953 & & \\
\hline \multirow{3}{*}{$\begin{array}{c}\text { Service } \\
\text { delivery } \\
\text { innovation } \\
\end{array}$} & SDI1 & 0.873 & \multirow{3}{*}{0.872} & \multirow{3}{*}{0.853} \\
\hline & SDI2 & 0.886 & & \\
\hline & SDI3 & 0.921 & & \\
\hline \multirow{3}{*}{$\begin{array}{c}\text { Service } \\
\text { innovation } \\
\text { performance }\end{array}$} & SIP1 & 0.902 & \multirow{3}{*}{0.887} & \multirow{3}{*}{0.895} \\
\hline & SIP2 & 0.876 & & \\
\hline & SIP3 & 0.898 & & \\
\hline
\end{tabular}

\subsection{The Test of Structural Equation Model}

According to the theoretical model and research hypothesis of this paper, using AMOS20.0 software, we can build structural equation model of the forming paths of cloud computing for the regional logistics information platform service innovation, paths analysis of structural equation model shown in Figure 2. In the path analysis model, 
flexibility and Integration latent variable of cloud computing act on service concept innovation of the three latent variables. The 3 latent variables also act on latent variable of service innovation performance. They form a cause and effect relationship which is reflected by the path formed by the 9 hypothesis. In this paper, we mainly use Chi-square/ratio, RMSEA, GFI, TLI, CFI, IFI, etc to evaluate the fit of the model, fitting index value of model as shown in Table 4. The result shown, fitting index value of model conform to standard; the C.R. value of the path formed by the all hypothesis is more than 1.96 reference values, indicating $\mathrm{p}<0.05$ level, path coefficients are statistically significant. This shows that the fitting indicators are within the allowable range, it shows that the model and data fitting effect can accept. Therefore, the results show that all the six hypotheses proposed in this study are supported.

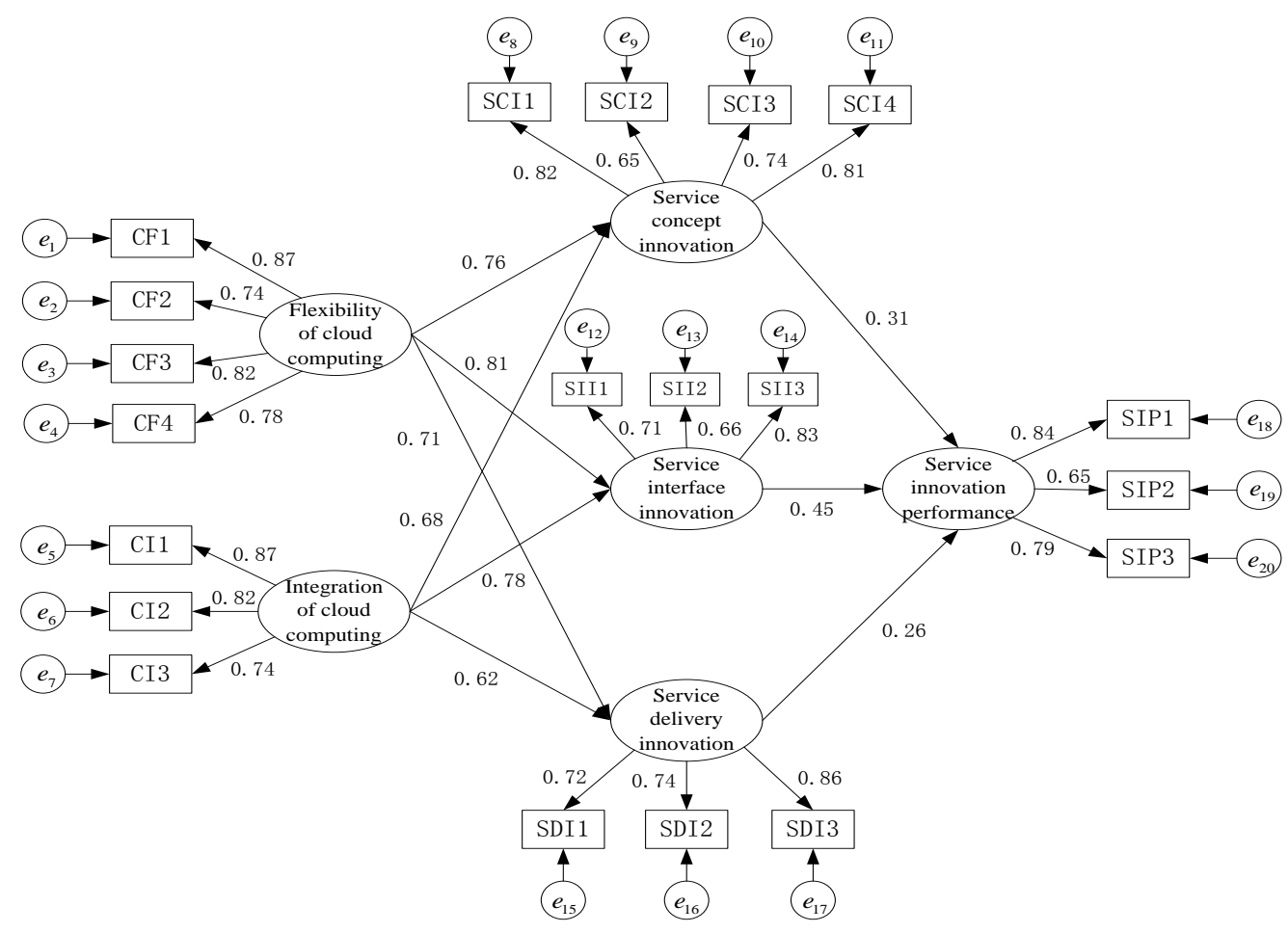

Figure 2. Path Analysis Model of Structural Equation

Table 4. Hypothesis Test of Structural Model

\begin{tabular}{c|c|c|c|c}
\hline $\begin{array}{c}\text { Hypothesi } \\
\mathrm{s}\end{array}$ & Corresponding path & $\begin{array}{c}\text { path } \\
\text { coefficien } \\
\mathrm{t}\end{array}$ & C.R. & $\begin{array}{c}\text { Test } \\
\text { result }\end{array}$ \\
\hline $\mathrm{H} 1$ & $\begin{array}{c}\text { Flexibility of cloud computing } \rightarrow \text { service } \\
\text { concept innovation of platform }\end{array}$ & 0.765 & 6.523 & Support \\
\hline $\mathrm{H} 2$ & $\begin{array}{c}\text { Integration of cloud computing } \rightarrow \text { service } \\
\text { concept innovation of platform }\end{array}$ & 0.682 & 5.124 & Support \\
\hline $\mathrm{H} 3$ & $\begin{array}{c}\text { service concept innovation of platform } \\
\rightarrow \text { service innovation performance }\end{array}$ & 0.315 & 3.124 & Support \\
\hline $\mathrm{H} 4$ & $\begin{array}{c}\text { Flexibility of cloud computing } \rightarrow \text { service } \\
\text { interface innovation of platform }\end{array}$ & 0.814 & 6.652 & Support \\
\hline $\mathrm{H} 5$ & $\begin{array}{c}\text { Integration of cloud computing } \rightarrow \text { service } \\
\text { interface innovation of platform }\end{array}$ & 0.782 & 6.557 & Support \\
\hline
\end{tabular}




\begin{tabular}{|c|c|c|c|c|c|c|}
\hline H6 & \multicolumn{3}{|c|}{$\begin{array}{l}\text { service interface innovation of platform } \\
\rightarrow \text { service innovation performance }\end{array}$} & 0.454 & 4.558 & Support \\
\hline $\mathrm{H} 7$ & \multicolumn{3}{|c|}{$\begin{array}{l}\text { Flexibility of cloud computing } \rightarrow \text { service } \\
\text { delivery innovation of platform }\end{array}$} & 0.716 & 5.746 & Support \\
\hline $\mathrm{H} 8$ & \multicolumn{3}{|c|}{$\begin{array}{c}\text { Integration of cloud computing } \rightarrow \text { service } \\
\text { delivery innovation of platform }\end{array}$} & 0.628 & 4.892 & Support \\
\hline H9 & \multicolumn{3}{|c|}{$\begin{array}{l}\text { service delivery innovation of platform } \\
\rightarrow \text { service innovation performance }\end{array}$} & 0.267 & 2.589 & Support \\
\hline Fit index & $\chi^{2} / \mathrm{DF}$ & RMSEA & GFI & TLI & CFI & IFI \\
\hline Specific figures & 1.837 & 0.062 & 0.952 & 0.931 & 0.974 & 0.942 \\
\hline
\end{tabular}

\subsection{Result Analysis of Hypothesis Test}

This paper chooses the information platform of logistics industry as an example. The structural equation model is applied to the study of the mechanism of information platform service innovation in cloud computing environment. The results are as follows:

(1) In the hypothesis test of service concept innovation, cloud computing and service concept innovation pass the test. The results show that the flexibility and integration of cloud computing has a positive effect on the service concept innovation. The flexibility of cloud computing can quickly respond to market changes and customer requirements, to provide personalized services for the customers. The integration of cloud computing can achieve dynamic sharing of information resources, dynamically allocate these shared resources according to the actual needs of users and meet the needs of customers with the least resources.

Service concept innovation and service innovation performance was positively correlated. Through a comprehensive analysis of the needs of customers, service concept innovation to provide customers with a new or improved service content or function. Information platform based on cloud computing can achieve a high concentration of information resources. Through the collection of large data, mining and processing of data information achieve rapid response to user needs, to provide a basis for decision-making services [19], thereby enhance the service innovation performance.

(2) In the hypothesis test of service interface innovation, the flexibility and integration of cloud computing has a positive effect on the service interface innovation. The flexibility of cloud computing which has great promotion on the innovation of service interface can solve the problem of information exchange and feedback between users and information platform at any time and any place through the network transmission between "cloud" and "client". The vivid display of service interface will attract customers and make customers get a better service experience. The integration of cloud computing reflects the platform to integrate a large number of information resources. Through the design and improvement of the platform service interface, which improve the breadth and depth of platform service to enhance the user value.

Service interface innovation has a positive effect on service innovation performance. Service interface innovation is a kind of element service activity of interactive relationship, interaction behavior and transferred information between actors, the core purpose of which is to build an interactive communication between the main bridge, to eliminate information flow barriers, to provide quality interactive environment for the improving of service innovation performance.

(3) In the hypothesis test of service delivery innovation, cloud computing and service delivery innovation pass the test. The results show that the flexibility and integration of cloud computing has a positive effect on service delivery innovation. The flexibility of cloud computing extend software architecture of platform, to ensure fluency of data and optimize the business process of the information platform. The integration of cloud 
computing can realize the visualization of service flow and increase the customer participation and transparency of services.

Service delivery innovation has a positive effect on service innovation performance. The information platform based on cloud computing can realize the dynamic sharing of information resources through resource integration [20], providing standardized, process data exchange and business collaboration services for customers, optimized the allocation of social resources by means of low cost, so as to provide customers with professional, personalized service and improve service innovation performance.

\section{Conclusion and Suggestion}

With the deepening of cloud computing applications, the explosive growth of corporate data resources under big data age, it will bring unlimited opportunities for development to information platform. Because of significant advantage of cloud computing technology, such as super-computing, mass storage, demand pay. It accelerates the development process of enterprise information and networking, it makes full technical support for the information platform, customizing integrated solutions for customers, meeting specialized, personalized needs of customers. Through the construction of the information platform can not only increase the communication and sharing of information, but also promote development of regional economic.

In this paper, through research on the mechanism of information platform service innovation in the cloud computing environment, the relationship among cloud computing technology, services innovation intermediate variables and service innovation performance analyze, to provide three innovative paths for the service mode innovation of information platform. Namely, based cloud service mode of service concept innovation, based cloud service mode of service interface innovation and based cloud service mode of service delivery innovation. With the passing of time, various information platforms can select an innovative path that depend on own situation, various information platforms can also choose the combination of several innovative paths to achieve service innovation. The limitation of this study is that three innovation variables are regarded as linear independent variables, without considering the coupling relationship among the various variables, and this topic will be further explored in the following research.

\section{Acknowledgement}

This research was supported by the National Natural Science Foundation of China under Grant 71473062, and Heilongjiang province Soft Science Research Program under Grant GC15D102, and Heilongjiang province the higher school of philosophy and social sciences innovation team project under Grant TD201203.

\section{References}

[1] R. Bilderbeek, D. Hertog and G. Marklund, "Service innovation: knowledge intensive business service as co-producers of innovation", (1998).

[2] L. Lei and W. Guisheng, "Service Management", Bei Jing: Qinghua University Press, (2008), pp. 80-82.

[3] D. Delen and H. Demirkan, "Data, Information and analytics as services", Decision Support Systems, vol. 55, no. 1, (2013), pp. 359-363.

[4] R. Buyya, C. Yeo, S. Venugopal, J. Broberg and I. Brandic, "Cloud computer and emerging it platforms", Future Generation Computer Systems, vol. 25, no. 6, (2009), pp. 599-616.

[5] Mcafee, "What every CEO needs to know about the cloud", Harvard Business Reviews, vol. 89, no. 11, (2011), pp. 124-132.

[6] W. Lin, W. Jiang and H. Shengrong, "Research on classification of service innovation", Technology Economics, vol. 28, no. 2, (2009), pp. 7-12.

[7] L. Changyun, "Innovations of business model caused by the next generation of information technology", China Soft Science, vol. 4, (2012), pp. 167-176.

[8] Y. Chao, H.Biqing and L.Fei, "Common key technology system of cloud manufacturing service platform for small and medium enterprises", Computer Integrated Manufacturing Systems, vol. 17, no. 3, (2011), 
pp. 496-503.

[9] Z.Fangfeng, L. Juntao and L. Bingwu, "Logistics public information platform design discussion under Cloud computing architecture", Journal of Commercial Economics, (2011), vol. 8, pp. 31-33.

[10] Y. Shuang, J. Xiaoqing and Z. Zhiqiang, "Function design of "Changchun and Jilin Integration" science and technology information sharing platform", Information Science, vol. 31, no. 7, (2013), pp. 29-32.

[11] C. Ye, "Strategies and paths of service innovation based on the new characteristics of service", Scientific Management Research, vol. 28, no. 4, (2010), pp. 7-10.

[12] H. Xinjun, Y. Shujun and T. Shilong, "Research on value create network under service-oriented manufacturing mode", Science \& Technology Progress and Policy, vol. 32, no. 9, (2015), pp. 60-66.

[13] W. Jiang, W. Lin, H. Shengrong and Taoyan, "The typology of innovation in knowledge-intensive business service", Studies in Science of Science, vol. 26, no. 10, (2008), pp. 195-201.

[14] S. Marston, Z. Li, S. Bandyopadhyay, J. Zhang and A. Ghalsasi, "Cloud Computing - Business Perspective”, Decision support systems, vol. 51, no. 1, (2011), pp. 176-189.

[15] L. Shunzhong, "The Interaction Mechanisms of Different Service Innovation Dimensions", Forum on Science and Technology in China, vol. 4, (2011), pp. 32-38.

[16] L. Yue, W. Hongqi and L. Changyun, "Research on wisdom service of regional science and technology resource sharing platform in the cloud computing environment", Study \& Exploration, vol. 7, (2015), pp. 112-115.

[17] J. Sundbo, "Management of innovation in services", The Service Industries Journal, vol. 17, no. 3, (1997), pp. 432-455.

[18] W. Minglong, "Structural equation model- Operation and application of AMOS", Chong Qing: Chongqing University Press, (2010), pp. 2-8.

[19] T. H. Davenport and J. G. Harris, "Competing on Analytics: The New Science of Winning", Harvard Business School Press, (2007), pp. 51-55.

[20] Y. Hongyu and T. Suning, "Cloud computing: System engineering of big data era”, Bei Jing: Publishing House of Electronics Industry, (2013), pp. 26-27. 
International Journal of Grid and Distributed Computing

Vol. 9, No. 10 (2016) 